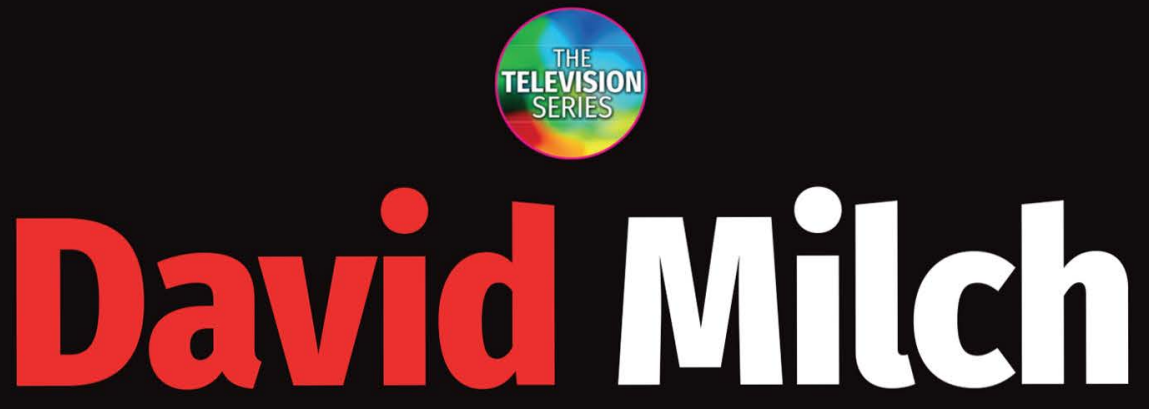

Jason Jacobs

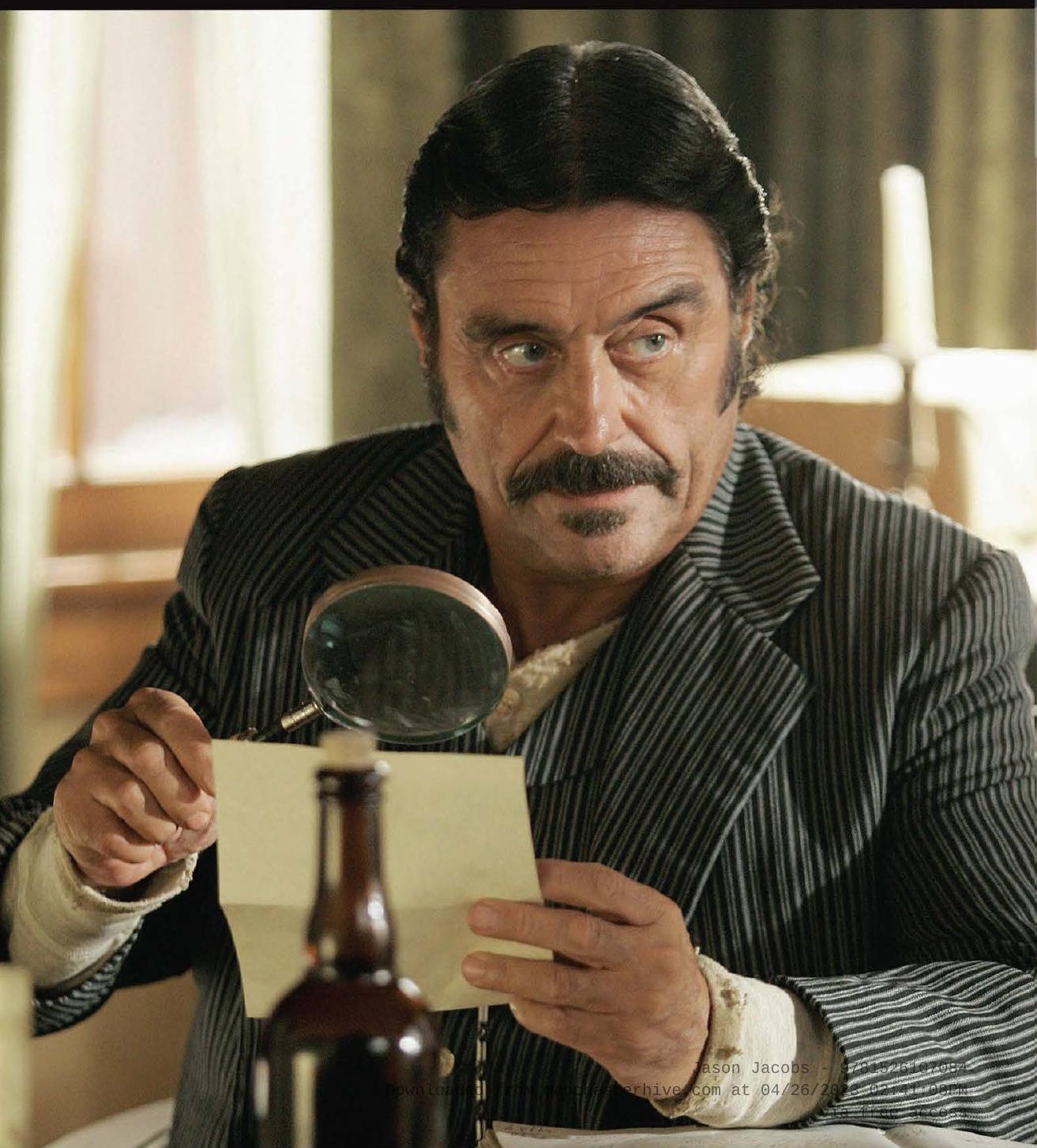




\section{David Milch}

\section{MANCHESTER 1824}

Manchester University Press 


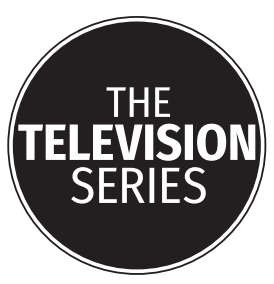

series editors

$$
\begin{aligned}
& \text { JONATHAN BIGNELL } \\
& \text { SARAH CARDWELL } \\
& \text { STEVEN PEACOCK } \\
& \text { already published }
\end{aligned}
$$

Paul Abbott BETH LOUISE JOHNSON

Alan Bennett KARA MCKECHNIE

Alan Clarke DAVE ROLINSON

Jimmy McGovern STEVE BLANDFORD

Andrew Davies SARAH CARDWELL

Tony Garnett STEPHEN LACEY

Trevor Griffiths JOHN TULLOCH

Troy Kennedy Martin LEZ COOKE

Terry Nation JONATHAN BIGNELL AND ANDREW O'DAY

Jimmy Perry and David Croft SIMON MORGAN-RUSSELL

Lynda La Plante Julia Hallam

Jack Rosenthal SUE VICE

Joss Whedon MATTHEW PATEMAN 


\section{JASON JACOBS}

\section{David Milch}

Manchester University Press 
Copyright (C) Jason Jacobs 2020

The right of Jason Jacobs to be identified as the author of this work has been asserted by him in accordance with the Copyright, Designs and Patents Act I988.

Published by Manchester University Press

Altrincham Street, Manchester Mi 7JA

www.manchesteruniversitypress.co.uk

British Library Cataloguing-in-Publication Data

A catalogue record for this book is available from the British Library

ISBN 978 o 7I90 83433 hardback

First published 2020

The publisher has no responsibility for the persistence or accuracy of URLs for any external or third-party internet websites referred to in this book, and does not guarantee that any content on such websites is, or will remain, accurate or appropriate.

Cover image: Ian McShane as Al Swearengen in Deadwood. AF archive / Alamy Stock Photo.

Typeset in Scala by

Servis Filmsetting Ltd, Stockport, Cheshire 